\title{
Multidrug-resistant bacteria in unaccompanied refugee minors arriving in Frankfurt am Main, Germany, October to November 2015
}

\author{
U Heudorf ${ }^{1}$, B Krackhardt ${ }^{1}$, $M$ Karathana ${ }^{1}$, N Kleinkauf ${ }^{1}$, C Zinn ${ }^{2}$ \\ 1. Public Health Department, Frankfurt, Germany \\ 2. Center for Hygiene and Infection Prevention, Ingelheim, Germany
}

Correspondence: Ursel Heudorf (ursel.heudorf@stadt-frankfurt.de)

Citation style for this article:

Heudorf U, Krackhardt B, Karathana M, Kleinkauf N, Zinn C. Multidrug-resistant bacteria in unaccompanied refugee minors arriving in Frankfurt am Main, Germany, October to November 2015. Euro Surveill. 2016;21(2):pii=30109. DOI: http://dx.doi.org/10.2807/1560-7917.ES.2016.21.2.30109

Many refugees arriving in Germany originate or have travelled through countries with high prevalence of multidrug-resistant Gram-negative organisms. Therefore, all unaccompanied refugee minors ( $\$ 18$ years-old) arriving in Frankfurt am Main between 12 October and 6 November 2015, were screened for multidrug-resistant Enterobacteriaceae in stool samples. Enterobacteriaceae with extended spectrum beta-lactamases (ESBL) were detected in 42 of $119(35 \%)$ individuals, including nine with additional resistance to fluoroquinolones ( $8 \%$ of total screened), thus exceeding the prevalences in the German population by far.

We report multidrug-resistant Enterobacteriaceae in stool samples of unaccompanied refugee minors ( $\$ 18$ years-old) arriving in Frankfurt am Main, Germany, between 12 October and 6 November 2015. Of 119 individuals screened in this study, extended spectrum beta-lactamase (ESBL)-producing Enterobacteriaceae were found in $42(35 \%)$, including nine with additional resistance to fluoroquinolones ( $8 \%$ of total screened), i.e. 3-multidrug-resistant Gram-negative bacteria (MDR GNB).

\section{Microbiological investigation}

All unaccompanied refugee minors arriving without their parents and families in Frankfurt am Main, Germany, from 12 October to 6 November 2015 were screened for multidrug-resistant Enterobacteriaceae in stool samples with informed consent of their legal caregivers. The enterobacteria were classified as 3MDR GNB or 4MDR GNB according to the phenotypic definition of the German commission on hospital hygiene and infection prevention (Kommission für Krankenhaushygiene und Infektionsprävention), i.e. Enterobacteriaceae resistant against three of four antibiotic groups (penicillins with piperacillin as surrogate substance, cephalosporins with cefotaxime and/or ceftazidime as surrogate substance, and fluoroquinolones with ciprofloxacin as surrogate substance) were part of $3 M D R$ GNB, while bacteria characterised as 4 MDR GNB had additional resistance against carbapenems, with imipenem and/ or meropenem as surrogate substance [1]. MDR GNB detection was performed by plating stools on ESBL and Klebsiella pneumoniae carbapenemase (KPC) chromagar selective media (Mast, Reinfeld, Germany). For identification and susceptibility testing of resistant colonies, matrix-assisted laser desorption ionization (MALDI), Biotyper mass spectrometry (Bruker Daltonics, Bremen, Germany) and VITEK 2 (BioMerieux, Nürtingen, Germany) with Clinical and Laboratory Standards Institute (CLSI) interpretative standards were used $[2,3]$. ESBL phenotypes were confirmed using double disk synergy testing [4]. Decreased carbapenem susceptibility in Enterobacteriaceae was confirmed using Etest and carbapenemase detection was performed using a modified Hodge test [2].

\section{Laboratory findings}

Of a total of 119 individuals screened, ESBL-producing Enterobacteriaceae were detected in $42(35 \%)$, including nine 3 MDR GNB ( $8 \%$ of total screened). No 4 MDR GNB was observed. Six (5\%) of the 119 refugees reported having a prior antimicrobial therapy, and two ( $2 \%)$ reported a hospital admission during the preceding six months. Among the 42 with ESBL-producing bacteria, two had received prior antimicrobial treatment in the past six months and one had been hospitalised, whereas one of nine refugees colonised with 3MDR GNB reported an antimicrobial treatment, with no hospital stay in this group.

In total, 37 Escherichia coli (thereof 9 3MDR GNB) and five $K$. pneumoniae (non-3MDR GNB) were detected. Whereas ESBL-producing bacteria were detected in persons from nearly all of the countries of origin (except Iraq, Iran, Libya, Senegal), 3MDR GNB were found only 
Detection of extended spectrum beta-lactamase-producing Enterobacteriaceae and thereof multidrug-resistant Gramnegatives in unaccompanied refugee minors arriving in Frankfurt am Main, Germany, 12 October-6 November 2015 $(\mathrm{n}=119)$

\begin{tabular}{|c|c|c|c|c|}
\hline Country of origin & Number of persons tested & $\begin{array}{l}\text { Number of individuals with ESBL- } \\
\text { producing Enterobacteriaceae }\end{array}$ & $\begin{array}{l}\text { Number of individuals with } \\
\text { 3MDR GNB }\end{array}$ & $\begin{array}{l}\text { Number of individuals } \\
\text { with } 4 \text { MDR GNB }\end{array}$ \\
\hline Afghanistan & 80 & $34^{a}$ & $7^{\mathrm{b}}$ & 0 \\
\hline Eritrea & 9 & 1 & 0 & 0 \\
\hline Somalia & 7 & 2 & 1 & 0 \\
\hline Syria & 7 & 3 & 0 & 0 \\
\hline Ethiopia & 5 & 0 & 0 & 0 \\
\hline Iraq & 4 & 0 & 0 & 0 \\
\hline Pakistan & 3 & 1 & 1 & 0 \\
\hline Yemen & 1 & 1 & 0 & 0 \\
\hline Other ${ }^{c}$ & 3 & 0 & 0 & 0 \\
\hline Total n (\%) & 119 & $42(35)$ & $9(8)$ & o (o) \\
\hline
\end{tabular}

ESBL: extended spectrum beta-lactamase; GNB: Gram-negative bacteria; MDR: multidrug-resistant.

a 29 Escherichia coli, 5 Klebsiella pneumoniae.

b 7 . coli.

'Iran, Libya, Senegal.

in persons coming from Afghanistan, Pakistan, and Somalia (Table).

\section{Discussion and conclusion}

There is a dramatic influx of refugees to the European Union under way, with more than 600,000 applications for asylum during the first nine months of 2015 in Germany [5]. Many refugees are coming from countries with high prevalence of multidrug-resistant organisms (MDRO) in hospital and community settings, such as Afghanistan, the Near and Middle East and the North African countries [6]. Additionally, many of the refugees coming from the Near and Middle East have been travelling through countries with high prevalences of MDROs, such as Turkey or Greece [7-9], whereas those coming from Africa are travelling via the 'West-Route', i.e. via Libya and Italy. A current European Centre for Disease Prevention and Control (ECDC) report showed high prevalence of carbapenem resistance and other antimicrobial resistances in Turkey and Greece in the period from 2013 to 2014 [7-9]. On that account, the Robert Koch Institute, Germany, has recommended in October 2015, screening refugees for MDRO on hospital admission in Germany [10]. Preliminary work on screening of 143 refugees admitted to the University Clinic of Frankfurt, Germany has been undertaken [11], however no data have so far been available on MDR GNB prevalences in young healthy refugees.

Here we report the first data on prevalence of $3 M D R$ GNB and ESBL-producing bacteria in unaccompanied refugee minors arriving in the country. ESBLproducing Enterobacteriaceae were found in $35 \%$ of the individuals included in our study and among these, 3 MDR GNB were found in $8 \%$ of the total individuals screened. To compare with estimates for the German population, between 2009 and 2012, Valenza et al. had tested 3,344 persons residing in the southern part of Germany, with $6.3 \%$ exhibiting ESBL, including 3MDR GNB, which occurred in $1.8 \%$ of those tested [12]. The MDR GNB prevalence in the young refugees exceeded these values by four- to fivefold.

In the Rhine-Main region, Germany, in the 2012 to 2015 period, prevalences for ESBL-producing bacteria and for 3 MDR GNB were respectively $7.5 \%$ and $3.8 \%$ in dialysis outpatients, and $7.7 \%$ and $3.8 \%$ in patients of rehabilitation clinics, i.e. only slightly exceeding the MDR GNB prevalences in the general population $[13,14]$. Patients depending on ambulatory care or residing in elderly care homes however, were more frequently colonised with bacteria having an ESBL phenotype or 3MDR GNB, with, in outpatients, $14.4 \%$ ESBL-producing bacteria and $7.6 \% 3$ MDR GNB, and in nursing home residents, 17.8 to $26.7 \%$ ESBL-producing bacteria and 12.3 to $21.3 \%$ 3MDR GNB [15-17]. Hence, colonisation with ESBL-producing Enterobacteriaceae in the unaccompanied refugee minors was also exceeding rates of bacteria with ESBL in all other patient groups tested in the Rhine-Main region recently, and 3MDR GNB colonisation rates were exceeding those in haemodialysis and rehabilitation patients with regular contact to the German medical system as well.

Prevalence of ESBL-producing Enterobacteriaceae in unaccompanied minors was higher than prevalence rates of patients transferred from hospitals abroad to the University Hospital Zurich, Switzerland, from 1 January 2009 to 30 September 2011: of them, 13.9\% were found with ESBL-producing bacteria, while $3 \mathrm{MDR}$ GNB prevalence was comparable $(7.6 \%$ refugees compared with $8.1 \%$ patients transferred to the university 
clinic) [18]. However, prevalence of $3 M D R$ GNB in the unaccompanied minors was still low compared with the data obtained by Reinheimer et al., who tested 143 refugee patients on admission to the University Hospital Frankfurt, Frankfurt/Main, Germany from June to December 2015 and compared the results to data on 1,489 non-refugee patients screened on admission as well. Prevalence of MDR GNB (ESBL-producing bacteria, 3 MDR GNB, and 4 MDR GNB) in refugee patients was $60.8 \%$, and thus exceeding the prevalence of MDR GNB in non-refugees (16.7\%) fourfold [11]. Our sample, however, encompassed only young people, most of them healthy, having fled on their own without their parents or families. This might explain the lower prevalence of MDR GNB in this group compared with that of the refugees on hospital admission. Nevertheless, both data support the demand for surveillance in refugees, not only for communicable disease [19] but also for MDRO [10].

\section{Conflict of interest}

None declared.

\section{Authors' contributions}

Prof. Heudorf and Dr. Niels Kleinkauf wrote and finalised the paper, Dr. Krackhardt and Mrs. Karathana organised the study. Dr. Zinn was responsible for the analytical results.

\section{References}

1. Hygienemaßnahmen bei Infektionen oder Besiedlung mit multiresistenten gramnegativen Stäbchen. Empfehlung der Kommission für Kranken-haushygiene und

Infektionsprävention (KRINKO) beim Robert Koch-Institut (RKI). [Hygiene measures for infection or colonization with multidrug resistant gram-negative bacilli. Commission recommendation for hospital hygiene and infection prevention (KRINKO at the Robert Koch Institute RKI)]. Bundesgesundheitsblatt Gesundheitsforschung Gesundheitsschutz. 2012;55(10):131154.PMID: 23011096

2. Clinical and Laboratory Standards Institute (CSLI). Performance standards for antimicrobial susceptibility testing; twentyfifth informational supplement. Wayne, Pa: CSLI;2015. CLSI document M100-S25.

3. El-Bouri K, Johnston S, Rees E, Thomas I, Bome-Mannathoko $\mathrm{N}$, Jones $\mathrm{C}$, et al. Comparison of bacterial identification by MALDI-TOF mass spectrometry and conventional diagnostic microbiology methods: agreement, speed and cost implications. Br J Biomed Sci. 2012;69(2):47-55.PMID: 22872927

4. Wiegand I, Geiss HK, Mack D, Stürenburg E, Seifert H. Detection of extended-spectrum beta-lactamases among Enterobacteriaceae by use of semiautomated microbiology systems and manual detection procedures.J Clin Microbiol. 2007;45(4):1167-74. DOI: 10.1128/JCM.01988-06 PMID: 17287329

5. European Asylum Support Office (EASO). Latest asylum trends. Number of applications for international protection in the EU+1. Valetta: EASO; September 2015. Available from: https:// easo.europa.eu/wp-content/uploads/Latest-Asylum-Trendssnapshot-Sept-2015.pdf

6. World Health Organization (WHO). Antimicrobial resistance. Global Report on Surveillance. Geneva: WHO; 2014. Available from: http://apps.who.int/iris/ bitstream/10665/112642/1/9789241564748_eng.pdf?ua=1

7. European Centre for Disease Prevention and Control (ECDC). Antimicrobial resistance surveillance in Europe 2014. Annual Report of the European Antimicrobial Resistance Surveillance Network (EARS-Net). Stockholm: ECDC; 2015. Available from: http://ecdc.europa.eu/en/publications/Publications/ antimicrobial-resistance-europe-2014.pdf
8. European Survey of Carbapenemase-Producing Enterobacteriaceae (EuSCAPE) working group,Albiger B, Glasner C, Struelens MJ, Grundmann H, Monnet DL. Carbapenemase-producing Enterobacteriaceae in Europe: assessment by national experts from 38 countries, May 2015. Euro Surveill. 2015;20(45):30062.PMID: 26675038

9. European Centre for Disease Prevention and Control (ECDC). Communicable disease risks associated with the movement of refugees in Europe during the winter season - 10 November 2015. Stockholm: ECDC; 2015. Available from: http://ecdc. europa.eu/en/publications/Publications/refugee-migranthealth-in-european-winter-rapid-risk-assessment.pdf

10. Robert Koch-institute (RKI). Screening von Asylsuchenden auf Multiresistente Erreger (MRE). [Screening of refugees for multidrug resistant bacteria]. Berlin: RKI; Oct 2015. [Accessed 5 Dec 2015]. German. Available from: http://www.rki.de/DE/Content/ Gesundheitsmonitoring/Gesundheitsberichterstattung/ GesundAZ/Content/A/Asylsuchende/Inhalt/MRE-Screening_ Asylsuchende.pdf?__blob=publicationFile

11. Reinheimer C, Kempf V, Göttig S, Hogardt M, Wichelhaus T, $\mathrm{O}^{\prime}$ Rourke $\mathrm{F}$, et al. Multidrug-resistant organisms detected in refugee patients admitted to a University Hospital, Germany June-December 2015. Euro Surveill. 2016;21(2):30110. DOI: 10.2807/1560-7917.ES.2016.21.2.30110

12. Valenza G, Nickel S, Pfeifer Y, Eller C, Krupa E, Lehner-ReindI V, et al. Extended-spectrum- $\beta$-lactamase-producing Escherichia coli as intestinal colonizers in the German community. Antimicrob Agents Chemother. 2014;58(2):1228-30. DOI: 10.1128/AAC.01993-13 PMID: 24295972

13. Dawson A, Mischler D, Petit C, Klein R, Heudorf U, Herrmann $M$. Prevalence of Methicillin-resistent Staphylococcus aureus in end stage renal failure patients in Saarland and Hessen.Int J Med Microbiol. 2012;302:87.

14. Heudorf U, Färber D, Mischler D, Schade M, Zinn C, Cuny C, et al. [Multidrug-Resistant Organisms (MDRO) in Rehabilitation Clinics in the Rhine-Main-District, Germany, 2014: Prevalence and Risk Factors]. Rehabilitation (Stuttg). 2015;54(5):339-45. DOI: 10.1007/s00103-013-1927-7 PMID: 24658671

15. Hogardt M, Proba P, Mischler D, Cuny C, Kempf VA, Heudorf $U$. Current prevalence of multidrug-resistant organisms in long-term care facilities in the Rhine-Main district, Germany, 2013. Euro Surveill. 2015;20(26):21171. DOI: 10.2807/1560-7917. ES2015.20.26.21171 PMID: 26159310

16. Heudorf U, Gustav C, Mischler D, Schulze J. Nosokomiale Infektionen, systemischer Antibiotikaeinsatz und multiresistente Erreger bei Bewohnern von Altenpflegeheimen. [Healthcare associated infections (HAI), antibiotic use and prevalence of multidrug-resistant bacteria (MDRO) in residents of long-term care facilities: the Frankfurt HALT plus MDRO project 2012]. Bundesgesundheitsblatt Gesundheitsforschung Gesundheitsschutz. 2014;57(4):414-22. DOI: 10.1007/s00103013-1927-7 PMID: 26505186

17. Neumann N, Mischler D, Cuny C, Hogardt M, Kempf VAJ, Heudorf U. Multidrug-resistant organisms (MDRO) in patients in outpatient care in the Rhine-Main district, 2014: Prevalence and risk factors.Bundesgesundheitsblatt Gesundheitsforschung Gesundheitsschutz. 2015. PMID:26631014

18. Nemeth J, Ledergerber B, Preiswerk B, Nobile A, Karrer S, Ruef $C$, et al. Multidrug-resistant bacteria in travellers hospitalized abroad: prevalence, characteristics, and influence on clinical outcome. J Hosp Infect. 2012;82(4):254-9. DOI: 10.1016/j. jhin.2012.08.017 PMID: 23103249

19. Catchpole M, Coulombier D. Refugee crisis demands European Union-wide surveillance!Euro Surveill. 2015;20(45):30063. PMID: 26606945

\section{License and copyright}

This is an open-access article distributed under the terms of the Creative Commons Attribution (CC BY 4.0) Licence. You may share and adapt the material, but must give appropriate credit to the source, provide a link to the licence, and indicate if changes were made.

This article is copyright of the authors, 2016. 